\title{
Contributory factors for the functional independence of oldest old
}

\author{
Fatores contributivos para a independência funcional de idosos longevos \\ Factores contributivos para la independencia funcional de ancianos longevos
}

Dâmarys Kohlbeck de Melo Neu Ribeiro ${ }^{1}$, Maria Helena Lenardt², Tatiane Michel ${ }^{3}$, Larissa Sayuri Setoguchi Clóris Regina Blanski Grden ${ }^{5}$, Edinaldo Silva de Oliveira ${ }^{6}$

\footnotetext{
${ }^{1} \mathrm{PhD}$ student in Nursing, Graduate Program in Nursing, Federal University of Paraná, Curitiba, PR, Brazil.

${ }^{2}$ Full Professor, Graduate Program in Nursing, Federal University of Paraná, Curitiba, PR, Brasil.

${ }^{3} \mathrm{PhD}$ in Nursing, Federal University of Paraná, Curitiba, PR, Brazil.

${ }^{4}$ Undergraduate student in Nursing, Federal University of Paraná, Curitiba, PR, Brazil.

${ }^{5}$ Assistant Professor, Department of Nursing, State University of Ponta Grossa, Ponta Grossa, PR, Brazil.

${ }^{6}$ Nurse, Clinics Hospital, Federal University of Paraná, Curitiba, PR, Brazil.
}

Correspondence Addressed to: Dâmarys Kohlbeck de Melo Neu Ribeiro Av. Pref. Lothario Meissner, $632,3^{\circ}$ andar, Jardim Botânico

CEP 80210-170 - Curitiba, PR, Brasil

E-mail: damy_neu@yahoo.com.br

\begin{abstract}
Objective: To investigate the socioeconomic and clinical factors that contribute to the functional independence of the oldest old of a community. Method: Cross-sectional quantitative study whose sample consisted of 214 elderly people registered in Basic Health Units. Data were collected through structured interviews and application of the Functional Independence Measure. We used descriptive statistics, and for association of the variables we used the Student t-test, ANOVA and Tukey's test for multiple comparisons. Results: The significant variables that contributed to the functional independence were remaining economically active, practicing physical and leisure activities, having a social life, eating fruits, vegetables and meat. The orientation to conduct these practices reduces the demand for care and help needed in everyday activities. Conclusion: Maintaining independence is primordial to delay disability and presents itself as an excellent field of work for nursing.
\end{abstract}

DESCRIPTORS

Aged; Aged, 80 and Over; Activities of Daily Living; Geriatric Nursing. 


\section{INTRODUCTION}

The oldest old, or older elderly, currently constitute the age group of the elderly population with the highest growth rate in Brazil and worldwide. These individuals have morphophysiological, psychological and socioeconomic differentiated features from other elderly. Heterogeneity is evident among the elderly, revealing that there are significant differences between the younger elderly (60-79 years) and those aged over 80 years $^{(1-2)}$.

However, little is known about the health status of the oldest old. National statistical institutes bring data from elderly in general and few specify the information about oldest old. According to the literature, the number of studies found on the oldest old does not follow the rapid growth of this age segment of the population, since is still not noticed an increase of national trends in research among these individuals ${ }^{(3)}$.

As a result of accelerated growth in the number of the oldest old, and the specificities of this age group, it is assumed that these elderly have less participation in society and a significant increase in demand for care. In order to determine this demand it is essential to assess functional capacity of the oldest old, which can be defined as "the ability of the individual to perform activities independently or everyday tasks, identified as essential for the maintenance of their well-being" ${ }^{\text {(4) }}$.

The elderly, who maintain their independence and selfdetermination - the ability of the individual to exercise their autonomy - should be considered a healthy elderly, even though they might show one or more chronic diseases $^{(5)}$. Thus, from the public health point of view , functional capacity emerges as a new component of the concept of health, suitable as an instrument to be implemented through a policy of attention to health of the elderly ${ }^{(6)}$.

One of the objectives to conduct the evaluation of the functionality in primary health care is early detection of functional impairment, since the presence of decline may signal changes not yet perceived and can generate disability and dependence ${ }^{(7)}$. The elderly evaluation of functionality is an important parameter in the practice of gerontology for providing relevant information on their health and on the need for outside help to perform activities of daily living ${ }^{(8)}$.

The functional assessment can be carried out through various instruments, including the Functional Independence Measure (FIM), which has been used in the elderly, because it considers not only the motor domain, but also the cognitive and social domains, important for assessing the functionality of these individuals ${ }^{(9)}$.

Early identification of elderly at risk for disability enables gerontological nursing to plan interventions aimed at enhancement of autonomy and reducing dependence. The inference about aspects that contribute or limit the functional independence is significant for the determination of individualized care plans, according to the potential and difficulties of each elderly.

The differential of this study is to investigate factors that positively contribute to the functional independence of oldest old. Thus, besides knowing socioeconomic and clinical aspects that interfere with the functionality of the elderly, we identified factors, which are positive for functional independence. Recognizing these aspects facilitates addressing actions in health of nursing professionals.

Given the above, the objective of this study was to assess the socioeconomic and clinical factors that contribute to the functional independence of the oldest old in a community.

\section{METHODS}

Quantitative cross-sectional study, conducted in the homes of the oldest old aged $\geq 80$ years, registered in one of the four Basic Health Units (BHU) in Curitiba, PR, selected by convenience.

Identification data of the oldest old were collected in Basic Health Units and home visits were scheduled. The population registered in these BHU was 417 oldest old. The simple random sample was calculated with a sampling error of $4.67 \%$ and $95 \%$ significance level. The size of the resulting sample was 214 oldest old. Inclusion criteria for the elderly were: aged 80 years old or more, be registered in one of the BHU from our research, be living at the registered domicile at the time of research, provide cognitive ability to participate. Exclusion criteria for the elderly were: to be living in a nursing home, to present significant difficulties in communication and express the desire to withdraw their participation in the study.

Data were collected at the homes of the oldest old in the presence of family caregivers, through structured interviews with questions related to socioeconomic and clinical aspects and application of the Functional Independence Measure (FIM) in the period from March to July 2012.

The Mini Mental State Examination (MMSE) ${ }^{(10)}$ was applied with the purpose of screening the elderly with cognitive ability to participate. For cognitive screening the cutoff points were used for the Brazilian population ${ }^{(11)}$. In cases in which the elderly did not reach cutoff score in the MMSE, the caregiver was invited to participate as an informant.

For the interview, we elaborated a data collection instrument, adapted from the Brazilian Institute of Geography and Statistics $(\mathrm{IBGE})^{(12)}$. In chart 1 , we indicated the variables of interest in the study that compose the socioeconomic profile, clinical profile and social life of the oldest old

Chart 1 - Variables of interest in the study - Curitiba-PR, 2012.

\begin{tabular}{|l|l|}
\hline SOCIOECONOMIC PROFILE & $\begin{array}{l}\text { Variables: gender, age, birthplace, skin color, education, marital status, number of children, with whom } \\
\text { she/he lives, income, current occupation. }\end{array}$ \\
\hline CLINICAL PROFILE & $\begin{array}{l}\text { Variables: health habits (physical activity, leisure activities, smoking, alcohol consumption), food, teeth } \\
\text { condition, use of assistive technologies, bedridden, the occurrence of falls, self-perceived health, diseases } \\
\text { reported, medication use, recent hospitalization. }\end{array}$ \\
\hline SOCIAL LIFE & Variables: participates in groups, often make visits, receives visits. \\
\hline
\end{tabular}


To evaluate functionality of the oldest old, we applied the Functional Independence Measure (FIM). The aim of this instrument is to quantitatively assess the burden of care that a person requires to perform motor and cognitive activities of daily living. The FIM is composed of a set of 18 tasks, including self-care, sphincter, mobility, communication, psychosocial and cognition, including memory, social interaction and problem solving. Each of these activities evaluated receives a score of 1 (total assistance) to 7 (complete independence). Thus, the total score ranges from 18 (total dependence) to 126 points (complete independence), representing the Total FIM scores (tFIM). The tFIM score can be subdivided according to the two areas of FIM, namely motor domain (mFIM), with possible score between 13 and 91, and cognitive domain (cFIM) that can vary between 5 and 35 points. This functional assessment instrument was validated in Brazil ${ }^{(13)}$.

Data collected were organized in spreadsheet and doublechecked, to reduce the possibility of error. The analysis were performed in the software R. In order to address the socioeconomic and clinical data, we used absolute and relative frequency, when the variables were qualitative, and measures of position (mean, minimum and maximum) and dispersion (standard deviation) for quantitative variables.
For the association of FIM values and the socioeconomic and clinical variables, we used the Student t test for variables that had only two levels, and ANOVA for variables with more than two levels. After conducting the analysis of variance, in case of significant difference between the levels, we used the Tukey test for multiple comparisons. For all statistical tests, a significance level of $95 \%$ were considered, when $p$ value was $<0.05$, they were considered statistically significant.

The study was approved by the Ethics Committee on Human Research, and the Municipal Health records under CAAE 0211.0.091.085-11, and 09/2012. The ethical principles of voluntary and informed participation of each subject were followed, according to the recommendations contained in Resolution no. 196 of the National Health Council of October $10^{\text {th }}, 1996^{(14)}$, valid on the date of referral to the Ethics Committee.

\section{RESULTS}

For the association between socioeconomic and clinical variables and the functional independence measure, we used as the dependent variable the average of the scores assigned to each activity calculated from the total FIM of the oldest old.

Table 1 - Variables associated with mean values of total FIM of the oldest old - Curitiba, PR, 2012.

\begin{tabular}{|c|c|c|c|}
\hline Variable & p-value & Variable & p-value \\
\hline Socioeconomic variables & & Corrective lenses & $<0.001^{* *}$ \\
\hline Gender & $0.21^{*}$ & Use of hearing aids & $0.04 *$ \\
\hline Age groug & $<0.001^{* *}$ & Occurrence of falls & $0.02 *$ \\
\hline Place o birth & $0.67^{*}$ & Recent hospitalization & $<0.001^{*}$ \\
\hline Skin color & $0.24^{* *}$ & Self-perceived health & $<0.001^{* *}$ \\
\hline Education & $0.55^{* *}$ & Cognitive impairment & $<0.001^{* *}$ \\
\hline Years of study & $0.05^{*}$ & Score on the MMSE & $<0.001^{* *}$ \\
\hline Maritual status & $0.50^{* *}$ & Pathologies reported & $0.35^{*}$ \\
\hline Has children & $0.91 *$ & Number of diseases & $0.14^{* *}$ \\
\hline Number of children & $0.01 *$ & Cardiovascular disease & $0.51 *$ \\
\hline Lives with & $<0.001^{* *}$ & Respiratory disease & $0.23^{*}$ \\
\hline Income & $0.42^{* *}$ & Endocrine-metabolic disease & $0.50^{*}$ \\
\hline Source of Income & $0.007^{*}$ & Musculoskeletal disease & $0.59^{*}$ \\
\hline Type of work during life & $0.3^{* *}$ & Stroke History & $<0.001^{*}$ \\
\hline Current occupation & $0.01 *$ & Neurological disease & $<0.001^{*}$ \\
\hline Social Life variables & & Psychiatric disease & $0.44^{*}$ \\
\hline Participates of Groups & $0.008^{*}$ & Urologic disease & $0.83^{*}$ \\
\hline Frequency of visits made & $<0.001^{* *}$ & Gastroenteric disease & $0.62 *$ \\
\hline Frequency of visits received & $0.03^{* *}$ & Visual deficit & $0.19^{*}$ \\
\hline Clinical variables & & Hearing deficit & $0.07 *$ \\
\hline Physical activity & $<0.001^{* *}$ & Medication Use & $0.58^{*}$ \\
\hline Leisure Activities & $<0.001^{*}$ & Quantity of medication & $0.96^{* *}$ \\
\hline Smoking & $0.45^{*}$ & Painkillers & $0.41^{*}$ \\
\hline Alcohol & $0.62^{*}$ & Vitamins & $0.91 *$ \\
\hline Consumption of fruits & $0.04^{* *}$ & CNS medication & $0.06^{*}$ \\
\hline
\end{tabular}


...continuation

\begin{tabular}{lclr}
\hline Variable & p-value & Variable & p-value \\
\hline Consumption of vegetables & $0.04^{* *}$ & Cardiovascular medication & $0.55^{*}$ \\
Consumption of milk and derivates & $0.14^{* *}$ & Blood medication & $0.48^{*}$ \\
Consumption of meat/chicken/fish & $0.02^{* *}$ & Gastrointestinal medication & $0.38^{*}$ \\
Condition of teeth & $<0.001^{* *}$ & Respiratory medication & $0.21^{*}$ \\
Use of assistive technologies & $<0.001^{* *}$ & Endocrine medication & $0.50^{*}$ \\
Bedridden & $<0,001^{*}$ & Osteoporosis medication & $0,03^{*}$ \\
\hline
\end{tabular}

Note: *Student t-test; **ANOVA

It is observed in Table 1 that five socioeconomic variables and 21 clinical variables were statistically significant compared with the average scores of the FIM. The multiple comparison test on the association of these significant variables to the average values in FIM allowed us to synthesize the negative and positive association that the variables presented in relation to functional independence (Chart 2).

Only the associations between the variables that contributed to the functional independence of the oldest old will be discussed. They are presented in Table 2 .

Chart 2 - List of significant variables according to their association with functional independence - Curitiba, PR, 2012.

\begin{tabular}{|l|l|}
\hline \multicolumn{1}{|c|}{ Variables that contribute to functional independence } & \multicolumn{1}{c|}{ Variables which limit functional independence } \\
\hline Being retired or pensioner & Being 90 years or more \\
Owning current occupation & Living with relatives \\
Performing physical activities & Making use of assistive technologies \\
Performing leisure activities & Occurrence of falls \\
Joining groups & Being bedridden \\
Receiving visitors & Recent hospitalization \\
Visiting relatives and friends & Reasonable health self-assessment \\
Consuming fruits, vegetables and meat & Cognitive impairment \\
& History of stroke, neurological disease \\
& Using medication for osteoporosis \\
\hline
\end{tabular}

Table 2 - Significant variables that contribute to functional independence associated to values of FIM dimensions, and multiple comparison test - Curitiba, PR, 2012

\begin{tabular}{|c|c|c|c|c|c|c|}
\hline Variable & Categories & $\begin{array}{l}\text { Mean } \\
\text { mFIM }\end{array}$ & $\begin{array}{l}\text { Mean } \\
\text { cFIM }\end{array}$ & $\begin{array}{l}\text { Mean } \\
\text { tFIM }\end{array}$ & Tukey (p-value) & p-value \\
\hline \multirow{2}{*}{ Source of income } & Retired and/or pensioner & 77.87 & 29.95 & 107.82 & & \multirow{2}{*}{0.007} \\
\hline & Family members' Income & 70.98 & 27.9 & 99 & & \\
\hline \multirow{2}{*}{$\begin{array}{l}\text { Current } \\
\text { ocupation }\end{array}$} & Yes & 85.54 & 32.25 & 117.9 & & \multirow{2}{*}{0.01} \\
\hline & No & 73.71 & 28.65 & 102.42 & & \\
\hline \multirow{3}{*}{$\begin{array}{l}\text { Does Physical } \\
\text { activity }\end{array}$} & Has done it & 83.59 & 31.95 & 115.56 & "Yes" and "has done it" $(0.001)^{*}$ & \multirow{3}{*}{$<0.001$} \\
\hline & Never & 71.24 & 27.7 & 99 & "Yes" and "Never" $(<0.001) *$ & \\
\hline & Yes & 71.76 & 28.1 & 99.9 & "Has done it" and "Never" (0.97) & \\
\hline \multirow{2}{*}{ Leisure Activities } & Yes & 78.13 & 30.25 & 108.36 & & \multirow{2}{*}{$<0.001$} \\
\hline & No & 53.69 & 21.4 & 75.06 & & \\
\hline \multirow{2}{*}{$\begin{array}{l}\text { Participates } \\
\text { of groups }\end{array}$} & Yes & 80.47 & 30.7 & 111.24 & & \multirow{2}{*}{0.008} \\
\hline & No & 73.19 & 28.55 & 101.7 & & \\
\hline \multirow{6}{*}{$\begin{array}{l}\text { Frequency of } \\
\text { visits made }\end{array}$} & & & & & "Does not visit" and "Always" $(<0.001)^{*}$ & \multirow{6}{*}{$<0.001$} \\
\hline & Does not visit & 66.82 & 26 & 92.88 & "Does not visit" and "Sometimes" $(<0.001)^{*}$ & \\
\hline & Always & 82.16 & 32.8 & 115.02 & "Does not visit" and "not often" (0.001)* & \\
\hline & Sometimes & 79.04 & 30.3 & 109.26 & "Always" and "Sometimes" (0.61) & \\
\hline & Not often & 81.64 & 30.7 & 112.32 & "Always" and "Not often" (0.97) & \\
\hline & & & & & "Sometimes" and "Not often" (0.95) & \\
\hline
\end{tabular}




\begin{tabular}{|c|c|c|c|c|c|c|}
\hline Variable & Categories & $\begin{array}{l}\text { Mean } \\
\text { mFIM }\end{array}$ & $\begin{array}{l}\text { Mean } \\
\text { cFIM }\end{array}$ & $\begin{array}{l}\text { Mean } \\
\text { tFIM }\end{array}$ & Tukey (p-value) & p-value \\
\hline \multirow{6}{*}{$\begin{array}{l}\text { Frequency of } \\
\text { visits received }\end{array}$} & & & & & "Not visited" and "Always" (0.02)* & \multirow{6}{*}{0.03} \\
\hline & Not visited & 69.68 & 25.7 & 95.22 & "Not visited" and "Sometimes" (0.52) & \\
\hline & Always & 77.09 & 30.95 & 108.18 & "Not visited" and "Not often" (0.91) & \\
\hline & Sometimes & 73.58 & 28.45 & 102.06 & "Always" and "Sometimes" (0.44) & \\
\hline & Not often & 72.67 & 26.75 & 99.36 & "Always" and "Not often" (0.43) & \\
\hline & & & & & "Sometimes" and "Not often" (0.97) & \\
\hline \multirow{3}{*}{$\begin{array}{l}\text { Consumption } \\
\text { of fruits }\end{array}$} & Always & 76.05 & 29.4 & 105.48 & "Always" and "Sometimes" (0.62) & \multirow{3}{*}{0.043} \\
\hline & Sometimes & 72.67 & 27.9 & 100.62 & "Always" and "Little" (0.04)* & \\
\hline & Little & 67.21 & 26.95 & 94.14 & "Sometimes" and "Little" (0.58) & \\
\hline \multirow{3}{*}{$\begin{array}{l}\text { Consumption } \\
\text { of vegetables }\end{array}$} & Always & 75.01 & 29.3 & 104.4 & "Always" and "Sometimes" (0.69) & \multirow{3}{*}{0.018} \\
\hline & Sometimes & 78.78 & 29.7 & 108.54 & "Always" and "Little" (0.03) * & \\
\hline & Little & 66.04 & 25.45 & 91.44 & "Sometimes" and "Little" (0.03) * & \\
\hline \multirow{3}{*}{$\begin{array}{l}\text { Consumption } \\
\text { of meat }\end{array}$} & Always & 75.79 & 29.35 & 105.12 & "Always" and "Sometimes" (0.99) & \multirow{3}{*}{0.023} \\
\hline & Sometimes & 76.05 & 29.45 & 105.48 & "Always" and "Little" (0.02) * & \\
\hline & Little & 66.95 & 26.4 & 93.42 & "Sometimes" e "Little" (0.06) & \\
\hline
\end{tabular}

NOTE: ${ }^{*} \mathrm{p}<0.05$

\section{DISCUSSION}

We found in Table 2 that the oldest retired and/or pensioners have significantly higher FIM average $(p=0.007)$ of those who rely on the income of family. Note also that the oldest elderly who maintain a current occupation have higher averages of FIM $(\mathrm{p}=0.01)$ compared to those who are no longer in the labor market. These observations, seemingly contradictory, suggest that being economically active, either through pensions, or carrying out a paid job, contributes to functional independence.

Thus, the oldest old who remain economically active does not necessarily depend on a third party for their livelihoods, and are clearly more independent. In assessing the FIM, these elderly had high scores in activities such as problem solving and social interaction skills necessary to perform tasks such as managing their own money and shop.

The hierarchy of functional decline $e^{(4,15)}$ explains, in part, the relationship between being economically active and functional independence. Instrumental activities of daily living are firstly affected in case of incapacity. Therefore, the oldest old that is still independent to carry out the daily life activities hardly presents dependence for basic activities such as bathing, or feeding.

A research that aimed to study the relationship between economic status and health, analyzing the impacts of income transfer policies for low-income elderly in Brazil, revealed a distinct improvement in the health status of older people in this economy class, so that changes income cause improvements in perceived health status ${ }^{(16)}$. Thus, the authors found that, in addition to health gains, transfer policies have changed the elderly role within the family, giving them greater autonomy, considering that many families are dependent on the income of the elderly and share of their inheritance. Current elderly have proved to be the main providers of family income, a situation which gives them greater appreciation within the family and society in general. The increase in management fees between the elderly and the reduction in the proportion residing with relatives suggest a decrease in dependence of the elderly ${ }^{(16)}$.

There was a statistically significant relationship between the variable physical activity and average scores on the elderly FIM investigated ( $p<0.001)$. The oldest old who practice physical activities presented a significantly higher FIM average than elderly people who did not practice, or have practiced exercises. There was no statistical difference between those who have never performed physical activities, and those who have in the past (Table 2).

The practice of physical activities, as discussed above, needs to be investigated among the oldest old. In the present study, we found that physical activities practiced by these elderly were mostly walking and stretching. Therefore, it can be considered that the practice of regular activities, even if less intense, was significantly associated with functional independence.

Literature review study with large population-based surveys on physical activity in elderly, aimed to describe the change in physical activity patterns in aging and the relationship of these changes to physical function and chronic diseases ${ }^{(17)}$. The author observed strong evidence that the health effects of moderate levels of activity are cumulative, regardless of physical fitness achieved by vigorous activities. Thus, the regular practice (30 minutes/day on most days of the week) of moderate intensity activities is beneficial (such as walking, climbing stairs, cycling, or housework and gardening), which accumulate daily energy expenditure and maintain muscle strength.

It is worth noting that the quality and quantity of physical activities beneficial to the oldest old are different from the activities recommended for other age groups, due to 
natural senescence changes. As a result of decreased exercise tolerance, a large and growing number of elderly people live below or only slightly above a threshold of physical fitness, in which the presence of a intercurrent disease can make them completely dependent ${ }^{(18)}$. Physical activity can help delaying the threshold of physical fitness and thereby improve physical functioning. With the improvement in physical function, there is a propensity to make larger amounts of activities that can be essential to the quality, and perhaps life expectancy of an elderly person ${ }^{(19)}$.

The variables "leisure activities" ( $<<0.001)$, "participates of a group" ( $p=0.008)$, "frequency of visits made" $(p<0.001)$, and "frequency of visits received" $(\mathrm{p}=0.03)$ were significantly related to the FIM. The oldest old who practice leisure activities and participates of groups have higher scores on the FIM; the oldest old who do not usually make visit and do not receive visits often present FIM significantly smaller compared to others.

These associations suggest that social participation and leisure positive influence on functional capacity. In this sense, these associations support the assertion that the continuity of the elderly in the labor market, for example, can be one of the intervention strategies to reduce disability in the elderly ${ }^{(20)}$.

The variables consumption of fruits, vegetables and meat were significantly related to the FIM ( $p=0.04 ; p=0.04$; $\mathrm{p}=0.02$, respectively). Considering the three variables together, we can inferred that: the elderly who have a habit of always consuming these foods have higher FIM average, and those who consume little had lower scores on the FIM.

This relationship suggests that good eating habits are important for the functional independence of the oldest old. It is noteworthy that in the present study we investigated only the current eating habits of oldest old, and dietary pattern during life certainly would have greater influence on the functional capacity. Another observation is that the association between functionality and nutritional status would possibly be stronger, considering body mass index and more detailed eating behaviors.

Systematic review of the literature was performed to evaluate whether the nutritional screening tools could predict mortality, functional decline and increased need for care $^{(21)}$. The results of this review indicated that the nutritional assessment scales are predictors of low risk of mortality and functional decline.
A research conducted with 2,948 Taiwanese elderly, over 65 years, sought to examine the predictive ability of functional status through Mini Nutritional Assessment $^{(22)}$. The authors state that nutritional status and functional capacity are mutually dependent, especially in the elderly, and found that the elderly classified as malnourished or at risk of malnutrition had a significantly higher risk of dependence in ADL and IADL compared to those who were classified as normal.

\section{CONCLUSION}

Given the above results, it can be inferred that being economically active, practicing physical and leisure activities, having a social life and the consumption of fruits, vegetables and meat are factors that contribute to the functional independence of the oldest old. Those who have these characteristics, practices and habits had higher scores on the FIM. This association suggests that, in general, oldest old who have an active aging process tend to stay independent. Maintaining this condition is primordial to delay disability and is presented as an excellent action field for nursing, as the orientation for these practices reduces the demand for care and help needed for everyday activities. It is believed, therefore, that the given results are the basis for decision making to nursing prescriptions aimed at physical activity and leisure, social and economic participation, and regular consumption of fruits, vegetables and meat.

All the elderly, before reaching the oldest elderly age, deserve attention in order to maintain independence, even those who at first have nothing, live in community with their families in stable health conditions. These individuals are usually forgotten, because the attention is focused on those who need special care due to some pathology and/ or serious deterioration. Thus, the gerontological nursing practice goes against this goal.

For the implementation of action plans for the oldest old who maintains some functional independence, investments are needed in health, allowing such actions. Additionally, in order to achieve the Active and Healthy Ageing, it is necessary to address special attention to our children and young people and their habits and lifestyles that are considered harmful to health. Thus, it is expected to partly revert the multi pathologies and comorbidities picture that is presented in oldest old today.

\section{RESUMO}

Objetivo: Verificar os fatores socioeconômicos e clínicos que contribuem para a independência funcional dos idosos longevos de uma comunidade. Método: Estudo quantitativo transversal cuja amostra foi constituída por 214 longevos cadastrados em Unidades Básicas de Saúde. Os dados foram coletados por meio de entrevista estruturada e aplicação da Medida de Independência Funcional. Utilizou-se estatística descritiva, e para associação das variáveis foram utilizados os testes t de Student e ANOVA, e o teste de Tukey para comparações múltiplas. Resultados: As variáveis significativas que contribuíram para a independência funcional foram: manter-se economicamente ativo, praticar atividades físicas e de lazer, possuir participação social, consumir frutas, verduras e carne. A orientação para a realização dessas práticas reduz a demanda de cuidados e necessidade de ajuda para as atividades cotidianas. Conclusão: A manutenção da independência é primordial para retardar incapacidades e apresenta-se como excelente campo de atuação para a enfermagem.

\section{DESCRITORES}

Idoso; Idoso de 80 anos ou Mais; Atividades Cotidianas; Enfermagem Geriátrica. 


\section{RESUMEN}

Objetivo: Verificar los factores socioeconómicos y clínicos que contribuyen para la independencia funcional de los ancianos longevos de una comunidad. Método: Estudio cuantitativo transversal cuya muestra estuvo constituida de 214 longevos registrados en Unidades Básicas de Salud. Los datos fueron recogidos mediante entrevista estructurada y aplicación de la Medida de la Independencia Funcional. Se utilizó una estadística descriptiva y, para la asociación entre las variables, se utilizaron las pruebas t de Student y ANOVA, y la prueba de Tukey para comparaciones múltiples. Resultados: Las variables significativas que contribuyeron para la independencia funcional fueron: mantenerse económicamente activo, practicar actividades físicas y de ocio, tener participación social, consumir frutas, verduras y carne. La orientación hacia la realización de dichas prácticas reduce la demanda de cuidados y la necesidad de ayuda para las actividades cuotidianas. Conclusión: El mantenimiento de la independencia es primordial para retardar las incapacidades y se presenta como excelente campo de actuación para la enfermería.

\section{DESCRIPTORES}

Anciano; Anciano de 80 o Más Años; Actividades Cotidianas; Enfermería Geriátrica.

\section{REFERENCES}

1. Rosset I, Roriz-Cruz M, Santos JLF, Haas VJ, Fabrício-Wehbe SCC, Rodrigues RAP. Socioeconomic and health differentials between two community-dwelling oldest-old groups. Rev Saúde Pública. 2011;45(2):391-400.

2. Marafon LP, Cruz IBM, Schwanke CHA, Moriguchi EH. Preditores cardiovasculares da mortalidade em idosos longevos. Cad Saúde Pública. 2003;19(3): 799-807.

3. Rosset I, Pedrazzi EC, Roriz-Cruz M, Morais EP, Rodrigues RAP. Tendencies of studies addressing the eldest individuals of aged population in the community: a (inter)national systematic review. Rev Esc Enferm USP. 2011;45(1):264-71.

4. Moraes EN. Princípios básicos de geriatria e gerontologia. Belo Horizonte: CoopMed; 2008.

5. Veras R. Population aging today: demands, challenges and innovations. Rev Saúde Pública. 2009;43(3):548-54.

6. Monteiro CR, Faro ACME. Functional evaluation of aged with fractures at hospitalization and at home. Rev Esc Enferm USP. 2010;44(3):719-24.

7. Brasil. Ministério da Saúde; Secretaria de Atenção à saúde, Departamento de Atenção Básica. Envelhecimento e saúde da pessoa idosa. Brasília; 2006. (Cadernos de Atenção Básica, 19).

8. Scattolin FAA, Colombo RCR, Diogo MJD. Preditores de independência funcional em idosos portadores de insuficiência cardíaca. Acta Fisiátrica. 2007;14(4):219-25.

9. Cruz KCT, Diogo MJD. Avaliação da capacidade funcional de idosos com acidente vascular encefálico. Acta Paul Enferm. 2009;22(5):666-72.

10. Folstein MF, Folstein SE, Mchugh PR. Mini-Mental State: a practical method for grading the cognitive status of patients for the clinician. J Psychiat Res. 1975;12(3): 189-98.

11. Bertolucci PHF, Brucki SM, Campacci SR, Juliano Y. O miniexame do estado mental em uma população geral : impacto da escolaridade. Arq Neuropsiquiatria. 1994;52(1): 1-7

12. Instituto Brasileiro de Geografia e Estatística (IBGE). Censo Demográfico 2000 - Migração e Deslocamento: resultados da amostra [Internet]. Rio de Janeiro; 2000. [citado 2011 nov. 2] Disponível em: http://www.ibge.gov.br/home/estatistica/populacao/censo2000/migracao/ censo2000_migracao.pdf

13. Riberto M, Miyazaki MH, Jucá SSH, Sakamoto H, Potiguara P, Pinto N, et al. Validação da versão brasileira da Medida de Independência Funcional. Acta Fisiátrica. 2004;11(2):72-6.

14. Brasil. Ministério da Saúde; Conselho Nacional de Saúde. Resolução n. 196, de 10 de outubro de 1996. Dispõe sobre as diretrizes e normas regulamentadoras de pesquisas envolvendo seres humanos. Bioética. 1996;4(2 Supl):15-25.

15. Njegovan V, Man-Son-Hing M, Mitchell SL, Molnar FJ. The Hierarchy of Functional Loss Associated With Cognitive Decline in Older Persons. J Gerontol A Biol Sci Med Sci. 2001;56(10): M638-43.

16. Neri MC, Soares WL. Estimando o impacto da renda na saúde através de programas de transferência de renda aos idosos de baixa renda no Brasil. Cad Saúde Pública. 2007;23(8):1845-56.

17. DiPietro L. Physical activity in aging: changes in patterns and their relationship to health and function. J Gerontol A Biol Sci Med Sci. 2001;56(spec 2):13-22.

18. Astrand PO. Physical activity and fitness. Am J Clin Nutr. 1992;55(6 Suppl):1231S-1236S.

19. Caspersen CJ, Kriska AM, Dearwater SR. Physical activity epidemiology as applied to elderly populations. Baillieres Clin Rheumatol. $1994 ; 8(1): 7-27$

20. Alves LC, Leite IC, Machado CJ. Factors associated with functional disability of elderly in Brazil: a multilevel analysis. Rev Saúde Pública. 2010;44(3):468-78.

21. Dent E, Visvanathan R, Piantadosi C, Chapman I. Nutritional screening tools as predictors of mortality, functional decline, and move to higher level care in older people: a systematic review. J Nutr Gerontol Geriatr. 2012;31(2):97-145.

22. Lee LC, Tsai AC. Mini-Nutritional-Assessment (MNA) without body mass index (BMI) predicts functional disability in elderly Taiwanese. Arch Gerontol Geriatr. 2012;54(3):405-10. 